
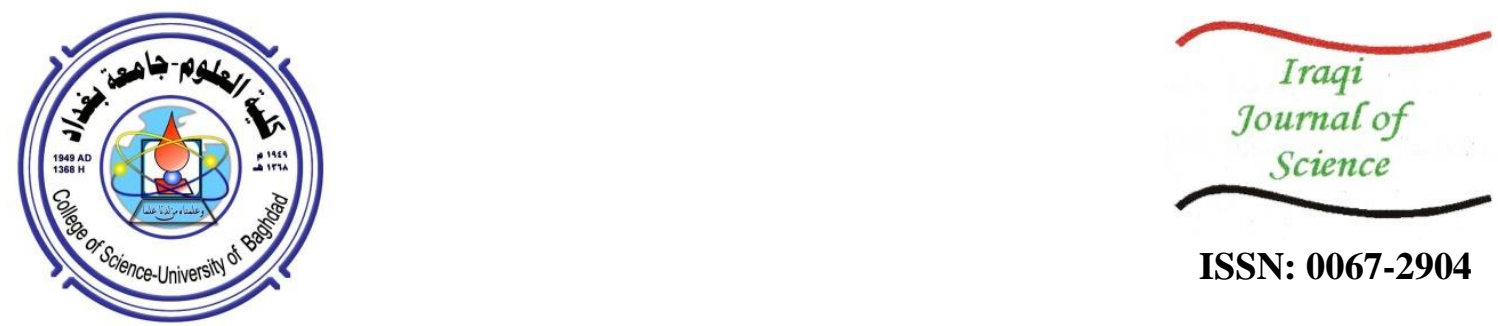

ISSN: 0067-2904

\title{
Air Pollution with Asbestos Fibers in Some Heavy Traffic Areas of Baghdad
}

\author{
Nahla Sh. Ajeel ${ }^{1 *}$, Nada A. Fleeh ${ }^{2}$, Matham A. Sultan ${ }^{3}$ \\ ${ }^{1}$ Department of Environment-Collage of Eng. University of Baghdad, Baghdad, Iraq \\ ${ }^{2}$ Department of Biology-Coll. of Sci. University of Baghdad, Baghdad, Iraq \\ ${ }^{3}$ Environmental Research Center, Ministry of Science and Technology, Baghdad, Iraq
}

Received: 28/7/2020

Accepted: 17/9/2020

\begin{abstract}
This research was conducted to measure the levels of asbestos fibers in the air of some dense sites of Baghdad city, which were monitored in autumn 2019. Samples collection was conducted via directing air flow to a mixed cellulose ester membrane filter mounted on an open-faced filter holder using sniffer with a low flow sampling pump. Air samples were collected from four studied areas selected in some high traffic areas of Baghdad city, two of them were located in Karkh (Al-Bayaa and AlShurta tunnel) and two in Rusafa (Al-Jadriya and Al-Meshin complex), then analyzed to determine concentrations of asbestos. Measuring of levels of asbestos fibers on the filters was carried out via using scanning electron microscope SEM together with an energy dispersive X-ray system (EDS). The results showed that the lowest level was recorded in Al-Jadriya intersection $(0.0352 \mathrm{fiber} / \mathrm{ml})$, while the maximum concentration was in Al-Bayaa $(0.156 \mathrm{f} / \mathrm{ml})$. Asbestos average concentration in the ambient air of the four studied areas was $0.0718 \mathrm{f} / \mathrm{ml}$, which exceeded the standards of world health organization (WHO) for air which is equal to $0.0022 \mathrm{f} / \mathrm{ml}$. This may be due to the presence of crowded traffic and the occurrence of industries near the city. Therefore, plans such as management of traffic, changing locations of industrial sites, and products substitution can be effective in minimizing the concentrations of airborne fibers .
\end{abstract}

Keywords: asbestos, SEM, EDS, high traffic, ambient air, autumn.

$$
\begin{aligned}
& \text { تلوث الهواء بألياف الأسبستوس في بعض مناطق المرور المزدحمة في بغداد } \\
& \text { نهلة شديد، ندى عبد الرحمن،ميثم عبد الله }
\end{aligned}
$$

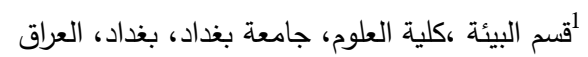

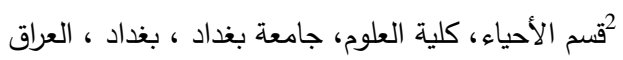

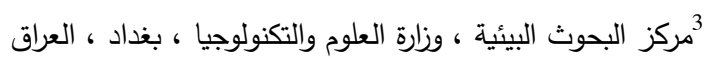$$
\text { الهدف من هذه الدراسة هو قياس مستويات ألياف الأسبستوز في الهواء المحيط في بعض المناطق }
$$

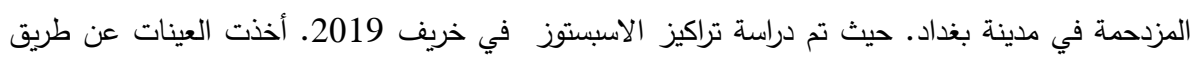

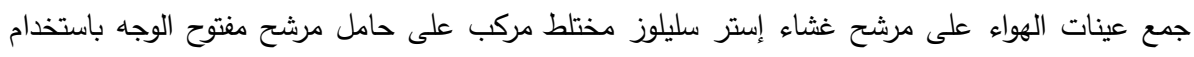

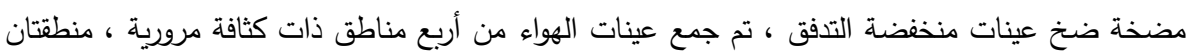




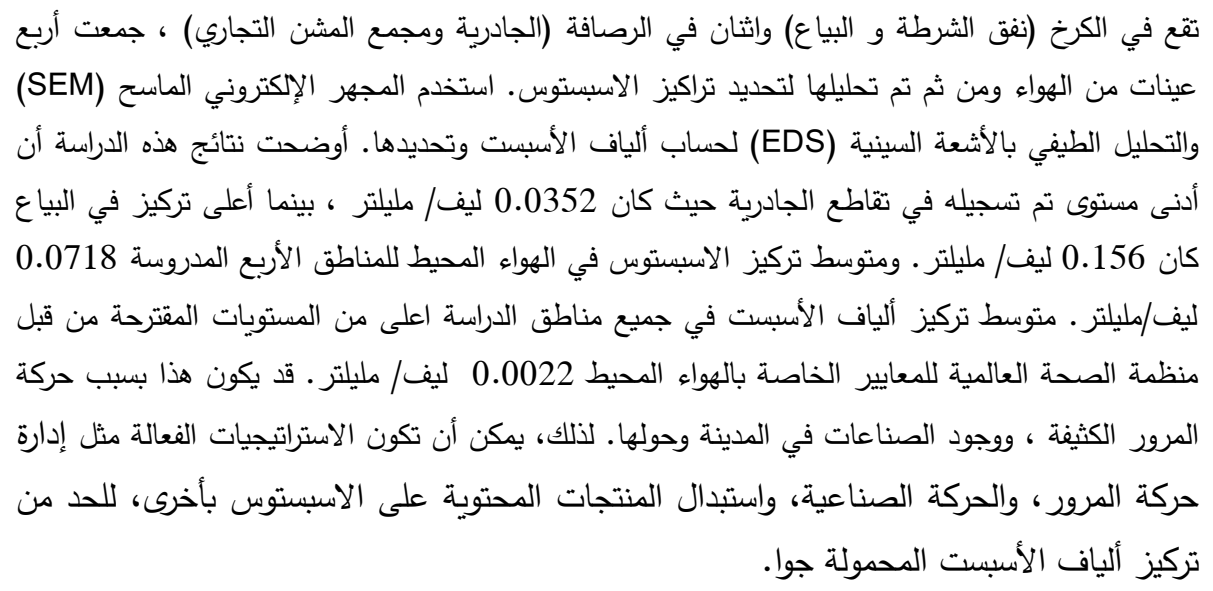

\section{Introduction}

Asbestos is a general name that applies to a group of carcinogenic and genotoxic thin fibers of silicate minerals which occur in crags and some types of soil [1], which have been of commercial important over the years [2]. They are easily separated into thin, long, and flexible fibers when crushed or processed [3]. Asbestos is formed from two groupsls, namely serpentine and amphibole [4]. Only fibers in the serpentine class are made of chrysotile mineral (white fibers) which has flexible and long fibers. Chrysotile is the predominant type of asbestos fibers produced and consumed in the world [5]. Amphiboles consist of five groups, which are the Crocidolite (blue fibers), Amosite (brown fibers), Actinolite, Tremolite and Anthophyllite. They are separated via chopping and processing which can lead to their diffusion in the environment with long, thin and flexible fibers [6]. Therefore, asbestos is a type of pollutants which is important among the particles in the air [7]. Because the unique and varied chemical and physical properties of asbestos, such as strength, flexibility, low conductivity and heat and chemicals resistance, these fibers are widely used in different industries like asbestos cement $[8,3]$, clutch and brake linings, building of construction materials for insulation, adhesives, vinyl asbestos, flooring, wall panels of canals for ventilation, and water and sewage systems' pipes, in addition to their use as a fire-retardant [8]. Because fibers of asbestos do not dissolve and evaporate, parts of fibers can enter the air and water from the weathering of natural sources and the wearing down of anthropogenic asbestos products [9]. Since mid-1960, there has been some evidence about serious health problems that can be caused by asbestos fibers, including lung cancer and mesothelioma [10]. Emission of tiny and microscopic fibers to air can be attributed to old and brittle products of asbestos. Asbestos fibers can stay suspended in the surrounding air and enter the lungs when inhaled.

Asbestos fibers inhalation causes many diseases of respiratory tract [11]. These fibers are dry and stretched that can be trapped in the bronchi, being finally transferred to the lung tissue and pleural space. When the asbestos fibers are inhaled, they can be trapped inside lungs and remain there for many years [6].

The correlation between the existence of asbestos fibers in human respiratory tract and malignant diseases like asbestosis, gastrointestinal cancer, laryngeal cancers, pleural effusion, pleural plaques and lung cancer has been approved [12]. Due to the lack of data about the levels of asbestos in the air in Iraq, providing such information is the necessary to develop effective management plans. The American environmental protection organization reported that 32 million kilograms of asbestos fibers are emitted annually into the environment, which is attributed to the corrosion of pads of vehicle brake [2]. Due to the sharp contact between the disc brakes containing asbestos fibers and gear plates, heavy weight cars eject severe account of asbestos into the surrounding air [13]. Since the inhalation of asbestos is undoubtedly known as carcinogenic.

\section{Materials and Methods}

Four areas were selected in some road intersections of Baghdad city, two located in Karkh (AlBayaa and Al-Shurta tunnel) and two in Rusafa (Al-Jadriya and Al-Meshin complex). The sampling was carried out during the day at various times in the downwind side of the location. The sniffer device was placed 1.5 meters higher than the ground level. The fibrous matters collected on the filter 
were identified and counted via using scanning electron microscope SEM (TESCAN DynaTOM, USA) and energy dispersive X-ray spectroscopy (EDX) [14].

Table 1- Short description of studied sites

\begin{tabular}{|c|c|c|c|c|}
\hline \multirow[t]{2}{*}{ No. } & \multirow{2}{*}{ Site name } & \multirow[t]{2}{*}{ Description } & \multicolumn{2}{|c|}{ Coordinates } \\
\hline & & & Latitude & Longitude \\
\hline 1 & Al-Bayaa & $\begin{array}{l}\text { Al-Bayaa is one of the popular areas } \\
\text { in the capital Baghdad due to its } \\
\text { population density. It is also one of } \\
\text { the important commercial cities of } \\
\text { the capital, considering the presence } \\
\text { of the famous and well-known } \\
\text { market (Street no. 20) as well as } \\
\text { another large market (Shorjah Al- } \\
\text { Karkh or Shorjah). } \\
\text { This vital district is located } \\
\text { southwest of Baghdad, at the edge of } \\
\text { Karkh side of the Tigris River, and } \\
\text { the highway (Airport Road) passes } \\
\text { through it, which also leads to the } \\
\text { central and southern governorates. }\end{array}$ & $\mathrm{N} 33^{\circ} 15^{\prime} 54^{\prime \prime}$ & $\mathrm{E} 44^{\circ} 20^{\prime} 9^{\prime \prime}$ \\
\hline 2 & Al-Jadriya & $\begin{array}{l}\text { Al-Jadriya is a neighborhood in } \\
\text { Baghdad, along the Tigris river. Al- } \\
\text { Jadriya shares a significant but } \\
\text { comparatively smaller part of the } \\
\text { peninsula with Karrada. Al-Jadriya is } \\
\text { at the south tip of the peninsula } \\
\text { where Tigris river makes its major } \\
\text { turn and heads to the north-east. } \\
\text { It has many shopping malls, services } \\
\text { and governmental institutions such } \\
\text { as University of Baghdad and many } \\
\text { hospitals, reflecting a picture of how } \\
\text { the area is crowded. It is also noted } \\
\text { that the region has scarce vegetation } \\
\text { cover. }\end{array}$ & $\mathrm{N} 33^{\circ} 16^{\prime} 5^{\prime \prime}$ & E $44^{\circ} 23^{\prime} 2^{\prime \prime}$ \\
\hline 3 & $\begin{array}{l}\text { Al-Meshin } \\
\text { complex }\end{array}$ & $\begin{array}{l}\text { Al-Meshin complex, a commercial } \\
\text { and industrial area characterized by } \\
\text { the presence of many factories with } \\
\text { different industrial activities from } \\
\text { the public and private sectors, } \\
\text { including the general company for } \\
\text { electrical industries, general } \\
\text { company for the manufacture of } \\
\text { batteries and electric poles, a factory } \\
\text { of dyes, and food industries. Also, } \\
\text { this site is crowded with high } \\
\text { numbers of vehicles and the use of } \\
\text { electric generators. }\end{array}$ & N $33^{\circ} 17^{\prime} 42^{\prime \prime}$ & E $44^{\circ} 27^{\prime} 3^{\prime \prime}$ \\
\hline 4 & $\begin{array}{l}\text { Al-Shurta } \\
\text { tunnel }\end{array}$ & $\begin{array}{l}\text { Al-Shurta is located southwest of } \\
\text { Baghdad on the Karkh side, and it is } \\
\text { an important commercial area in the } \\
\text { region, with a large vegetable market } \\
\text { and another for meat, along with } \\
\text { commercial markets for clothes and } \\
\text { mobile phones, and there are primary } \\
\text { and secondary schools for both } \\
\text { sexes. }\end{array}$ & $\mathrm{N} 33^{\circ} 18^{\prime} 2^{\prime \prime}$ & $\mathrm{E} 44^{\circ} 19^{\prime} 2^{\prime \prime}$ \\
\hline
\end{tabular}




\section{Sampling Sites}

Sites of sampling were selected by taking into account the density of traffic, intensity of population, pollutants of industrial origin, and direction of prevailing winds, as describe in Table-1.

Sniffer (SKC MCS Flite, Swedish) is a device used in the field to collect samples of air pollutants such as asbestos fibers, heavy metals, and total suspended particles TSP and the measurement unit is $1 / \mathrm{min}$.

Cellulose filters, before sampling, were dried at $40 \mathrm{C}^{0}$ for 30 minutes and then weighted to record initial weight $\left(\mathrm{W}_{\mathrm{i}}\right)$ by using a sensitive balance [15]. In the sampling location, the filter placed in the sampler sniffer device was put on a height of one meter or more above the ground, to avoid the dust by the movement of wind, and with the direction of the prevailing winds in the region $[6,16]$. Then at the end of sampling operation, the exposed filter removed was from the sampler, kept inside a sealed container, and weighted in the laboratory, which represents the final weight (Wf) [1].

Four samples from each site were collected. A map of the city and the sampling sites is illustrated in Figure-1. The filters were placed inside sealed plastic petri dishes and transferred to the nano laboratory of the minerals research office at the Iraqi Ministry of Science and Technology for preparation as well as SEM and EDS analyses.

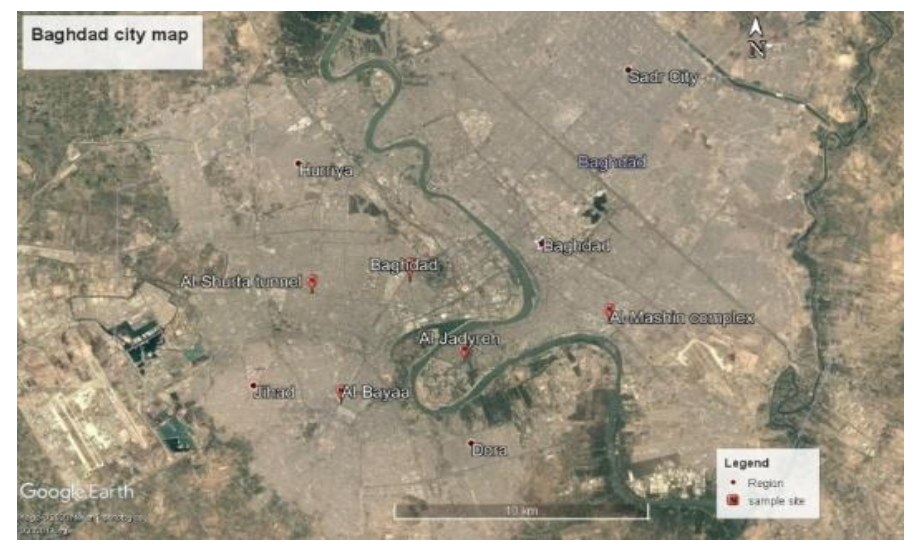

Figure 1- The map of collection sites showing Al-Jadriya, Al-Bayaa, Al-Meshin complex, and AlShurta tunnel

\section{Preparation and Analysis of Samples}

SEM along with EDS was used to detect the asbestos fibers. EDS method gives a spectrum showing elemental content of the fibers. Filters were analyzed_via SEM according to the method of BS ISO 14966 [17]. The filters were mounted on sample stub with two sided copper adhesive tape and then placed on coating device (EMITECH K 450X, EM Technologies Ltd. England) for coating by gold. Thereafter, SEM magnifications ranging from 500 to 10000 were used to detect fibers with length higher than $5 \mu \mathrm{m}$, diameter higher than $3 \mu \mathrm{m}$, and ratio of length to diameter of $3 / 1$ were considered as asbestos fibers. SEM sensitivity was reported to be in the scale of $0.0001 \mathrm{f} / \mathrm{ml}$ of air [18].

\section{Measuring the Concentration of Asbestos Fibers}

Based on SEM results, the concentrations of asbestos fibers were determined by following this equation $[6,16,19]$.

$\mathrm{C}_{\mathrm{SEM}}=(1000 * \mathrm{~N} * \mathrm{~A}) /\left(\mathrm{V}^{*} \mathrm{n} * \mathrm{a}\right)$

where

C: Concentration of asbestos fibers in the air in fibers/milliliter $(\mathrm{f} / \mathrm{ml})$,

$\mathrm{N}$ : Number of counted fibers,

A: Effective area of the filter (the area that varied in color compared with other areas of the filter due to flow of air stream), which was equal to $385 \mathrm{~mm}^{2}$,

$\mathrm{V}$ : Volume of sampled air (liter),

$\mathrm{n}$ : Number of counted fields of images, and

a: Calibrated area of each image $\left(\mathrm{mm}^{2}\right)$.

\section{Results and Discussion}


Based on the results of SEM, the concentration of the fibers was the highest in Al-Bayaa area $(0.156 \mathrm{f} / \mathrm{ml})$ and the lowest was in Al-Jadriya $(0.0352 \mathrm{f} / \mathrm{ml})$, as shown in Figure- 2. All these results exceed the standards level of the WHO which was set to be equal to $0.0022 \mathrm{f} / \mathrm{ml}$.

Those levels are higher than those measured in some other countries of the world. For example, in Romania, Anca reported an average level of $0.02702 \mathrm{f} / \mathrm{ml}$ from several points in Bucharest [20]. While in some cities in Italy, Gualtieri and his colleagues recorded an average level of $0.00056 \mathrm{f} / \mathrm{ml}$ $[21,22]$. Studies in Iran found that the average level of asbestos fibers was between $0.01364 \mathrm{f} / \mathrm{ml}$ and $0.01224 \mathrm{f} / \mathrm{ml}[6,16]$.

An examples of an SEM image of asbestos fibers is shown in Figure- 3. The highest level of asbestos was founded in Al- Bayaa, which is attributed to the commercial nature of this region, with the activities of repairing and construction of streets that led to densely-polluted roads In addition, it can be attributed to the heavily-crowded bus garages located near this area. Other high polluted site was Al-Shurta tunnel, which is an industrial region with heavy traffic in most times, in addition to the presence of old buildings that are considered as an important source of asbestos in the air.

The others two studied locations, Al-Jadriya and Al-Meshin complex, also recorded high levels of asbestos fibers due to the fact that they are commercial areas characterized by congested traffic. It is important to mention that natural sources such as weathering and erosion are among the important reasons for the spread of asbestos in the surrounding air $[22,23]$.

Table 2- Concentrations of airborne asbestos fiber by area

\begin{tabular}{|c|c|}
\hline Area name & concentration (fiber/ml) \\
\hline Al-Bayaa & 0.156 \\
\hline Al-Jadriya & 0.0352 \\
\hline Al-Meshin complex & 0.0871 \\
\hline Al-Shurta tunnel & 0.096 \\
\hline Average value & 0.0718 \\
\hline WHO & 0.0022 \\
\hline
\end{tabular}

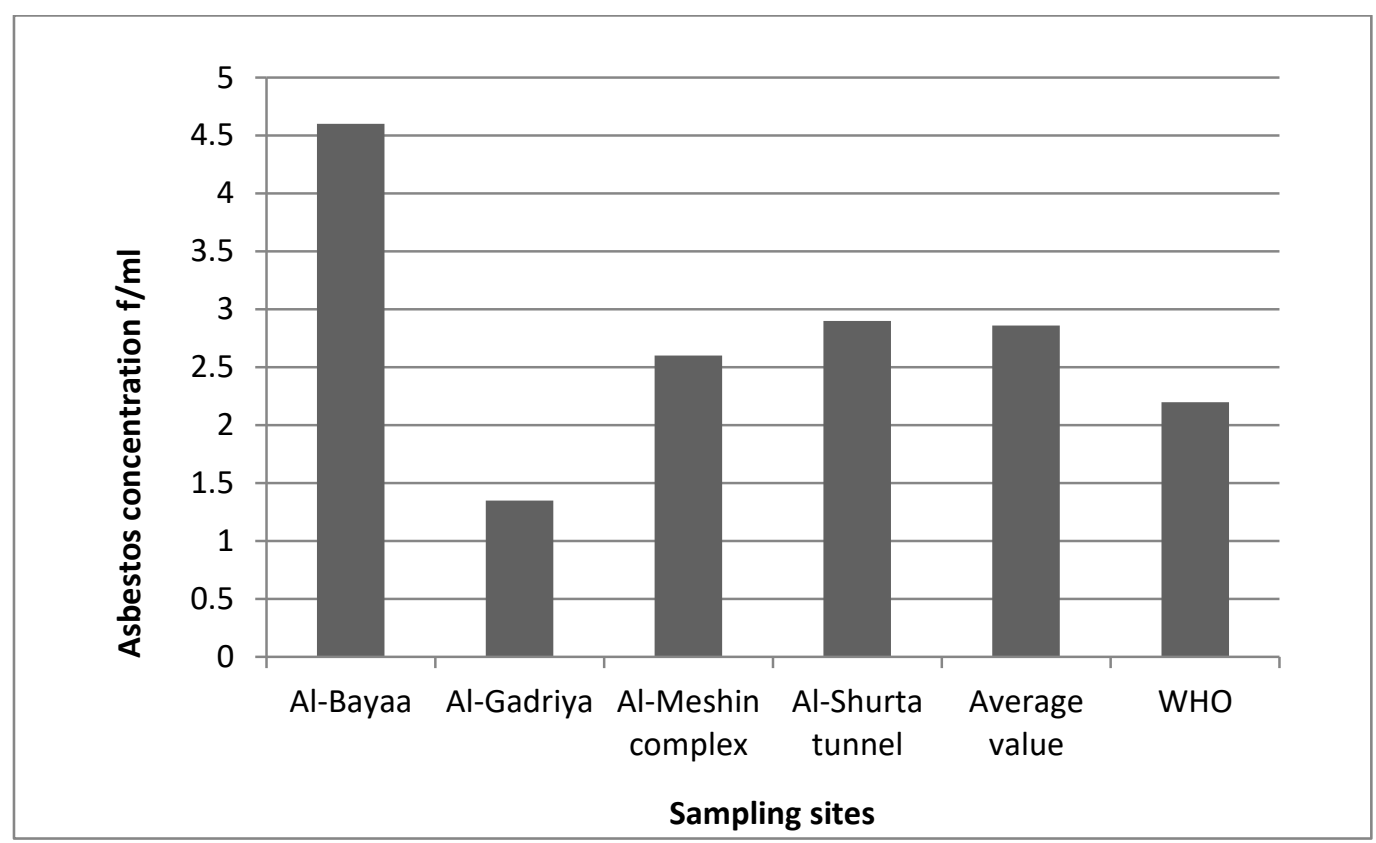

Figure 2- Concentration variation of asbestos fibers throughout the sampling sites as analyzed by SEM and their comparison with the WHO recommended standard 


\section{Relationship between Asbestos Level and Meteorological Factors}

Some parameters, such as speed of wind, temperature, and humidity were collected for each sampling day and correlated with the concentration of airborne asbestos fibers. The results revealed no notable relationship among levels of asbestos fibers and meteorological parameters $[24,25]$. These results are given in Table- 3 .

Table 3- Correlation between metrological parameters and concentration of asbestos fibers

\begin{tabular}{|c|c|c|c|c|}
\hline Area name & $\begin{array}{c}\text { Asbestos } \\
\text { concentratio } \\
\mathbf{n ~ f / m l}\end{array}$ & $\begin{array}{c}\text { Wind } \\
\text { speed } \\
\mathbf{m} / \mathbf{s}\end{array}$ & $\begin{array}{c}\text { Temperatur } \\
\mathbf{e ~ C}^{\mathbf{0}}\end{array}$ & $\begin{array}{c}\text { Relative } \\
\text { humidity \% }\end{array}$ \\
\hline Al-Bayaa & 0.156 & 1.5 & 15 & 62.6 \\
\hline Al-Jadriya & 0.0352 & 1.5 & 16 & 52.8 \\
\hline Al-Meshin complex & 0.0871 & 1 & 13.2 & 69.5 \\
\hline Al-Shurta tunnel & 0.096 & 1.5 & 14.5 & 71.3 \\
\hline
\end{tabular}

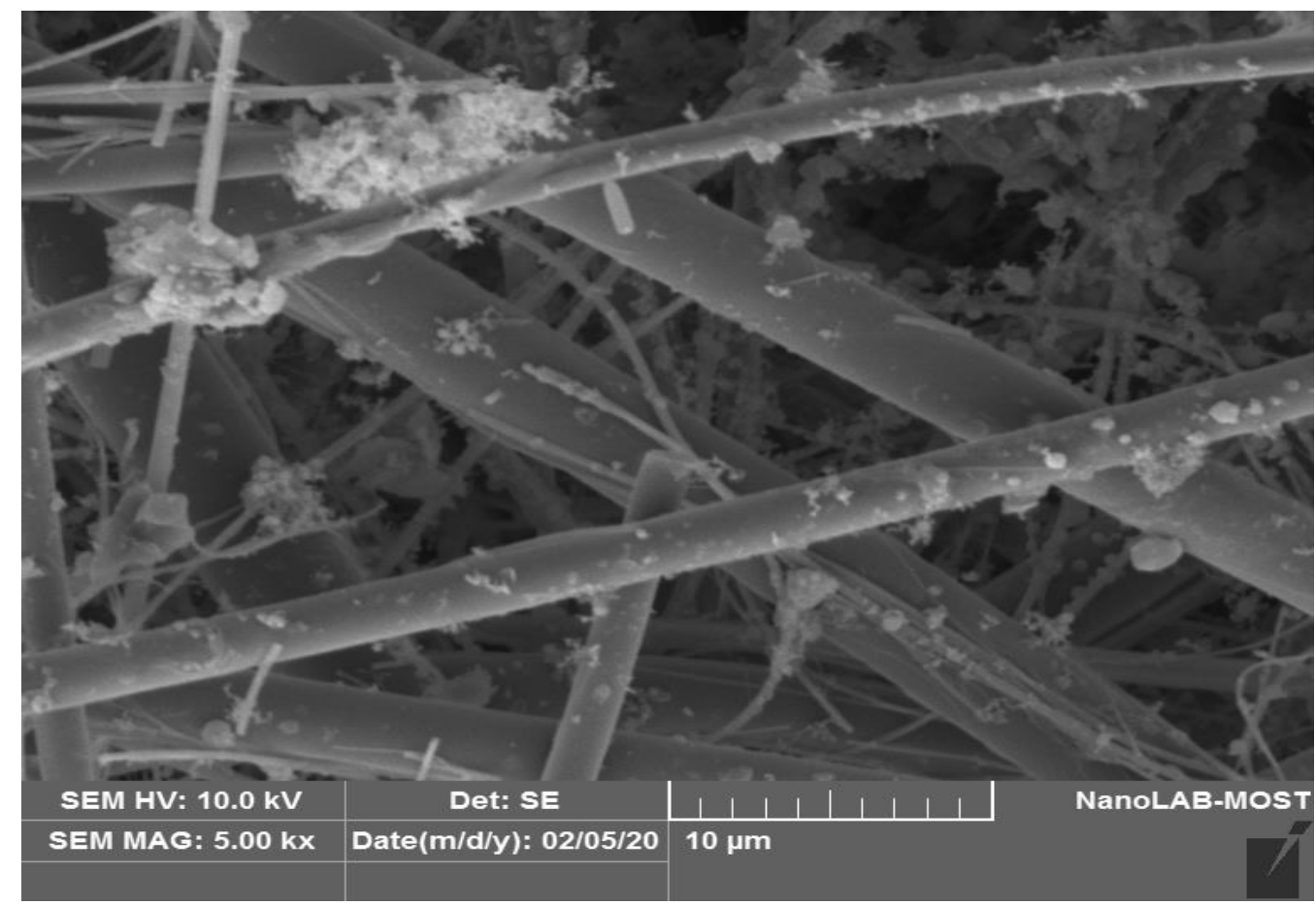

Figure 3- Scanning electron microscope image showing asbestos fiber (magnification 5,000X)

\section{Energy Dispersive X-Ray Spectrometry (EDX) Results}

Depending on the results obtained from the EDX analysis, the chemical composition of the asbestos fibers consisted mainly of magnesium $(\mathrm{Mg})$ and silica ( $\mathrm{Si}$ ). Accordingly, all samples collected from the four studied areas contained $\mathrm{Mg}$ and $\mathrm{Si}$ in their chemical composition. The results showed $\mathrm{Mg}$ content between $0.785-0.98 \%$, while the proportion of $\mathrm{Si}$ was between $21 \%-31 \%$. The chemical composition of the asbestos fibers is shown in Table- hj 4 and Figures- 4, 5, 6 and 7.

The results obtained from EDX analysis confirmed that asbestos fibers contained the elements that make them the most dangerous type of pollutants to human health [26, 27]; due to the type of chemical bonding between these elements, it is difficult to eliminate the fibers from a contaminated person because of their ability to bond tightly with tissues of the lungs $[28,29,30]$. 
Table 4- Chemical content in percentage of asbestos fibers

\begin{tabular}{|c|c|c|c|c|}
\hline Sampling site & Al-Bayaa & Al-Jadriya & Al-Shurta tunnel & $\begin{array}{c}\text { Al-Meshin } \\
\text { complex }\end{array}$ \\
\hline Element & Wt\% & Wt\% & Wt\% & Wt\% \\
\hline $\mathrm{C}$ & 7.73 & 12.11 & 15.53 & 20.19 \\
\hline $\mathrm{O}$ & 43.98 & 44.38 & 40.01 & 40.46 \\
\hline $\mathrm{Na}$ & 6.69 & 4.29 & 3.38 & 4.61 \\
\hline $\mathrm{Mg}$ & 0.78 & 0.98 & 0.94 & 1.22 \\
\hline $\mathrm{Al}$ & 3.10 & 3.64 & 2.5 & 2.59 \\
\hline $\mathrm{Si}$ & 31.21 & 23.45 & 21.92 & 20.05 \\
\hline $\mathrm{S}$ & 0.76 & 1.15 & 3.08 & 1.62 \\
\hline $\mathrm{Cl}$ & 0.30 & - & - & - \\
\hline $\mathrm{K}$ & 1.74 & 2.54 & 2.54 & 1.29 \\
\hline $\mathrm{Ca}$ & 3.72 & 6.82 & 11.51 & 7.97 \\
\hline $\mathrm{P}$ & - & - & 0.17 & - \\
\hline $\mathrm{Fe}$ & - & 0.65 & - & - \\
\hline $\mathrm{Total}:$ & 100.00 & 100.00 & 100 & 100.00 \\
\hline
\end{tabular}

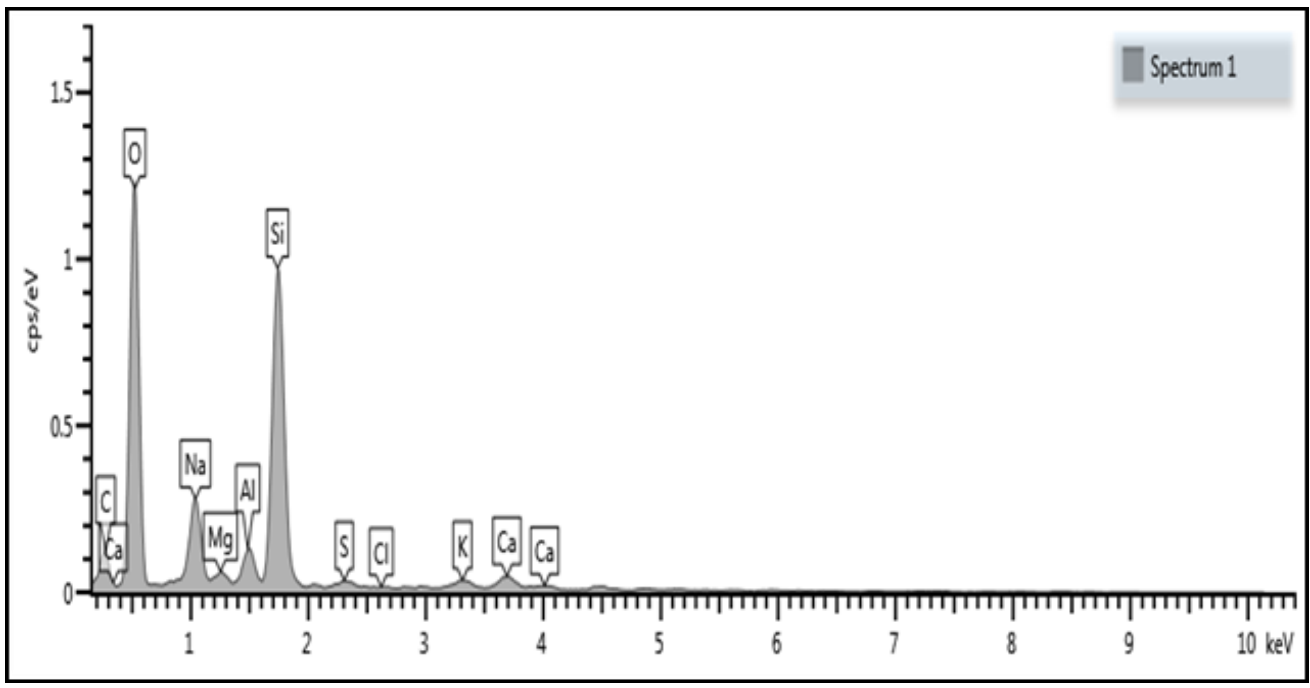

Figure 5- Results of EDS in SEM analysis of asbestos composition of Al- Bayaa air sample

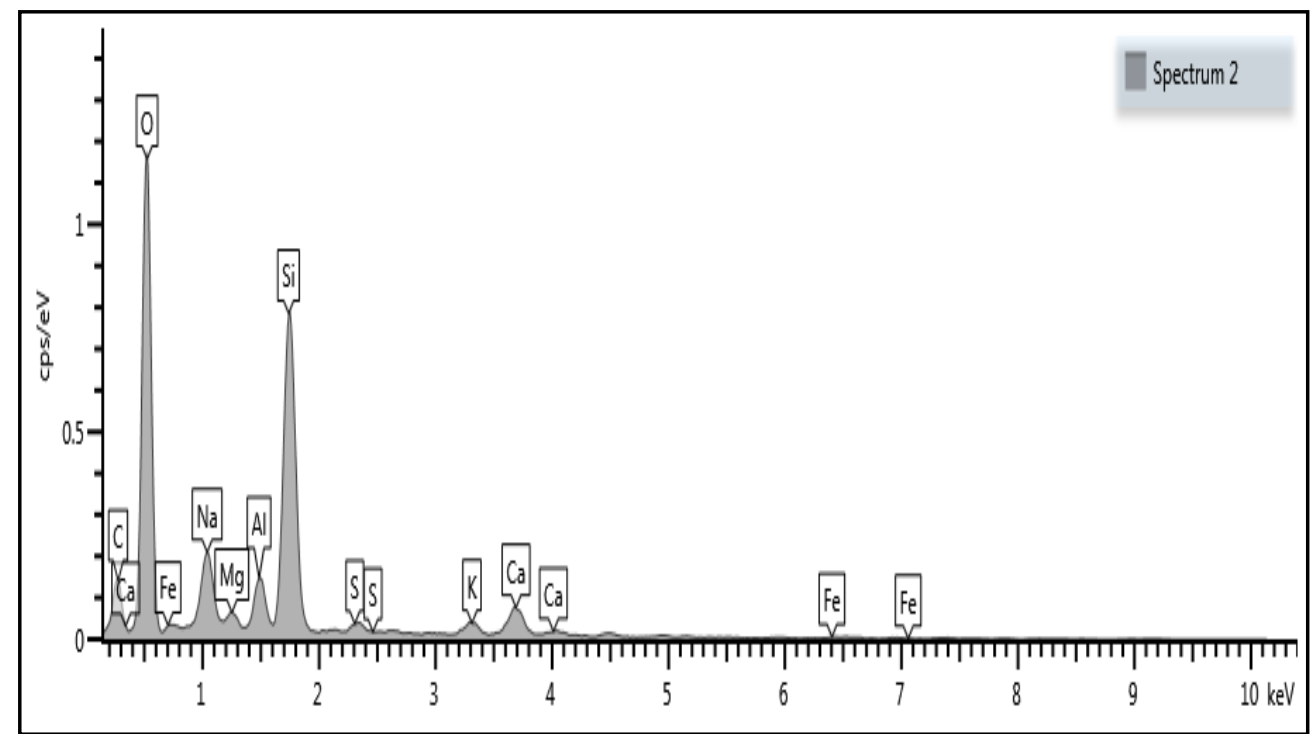

Figure 5- Results of EDS in SEM analysis of asbestos composition of Al-Jadriya air sample 


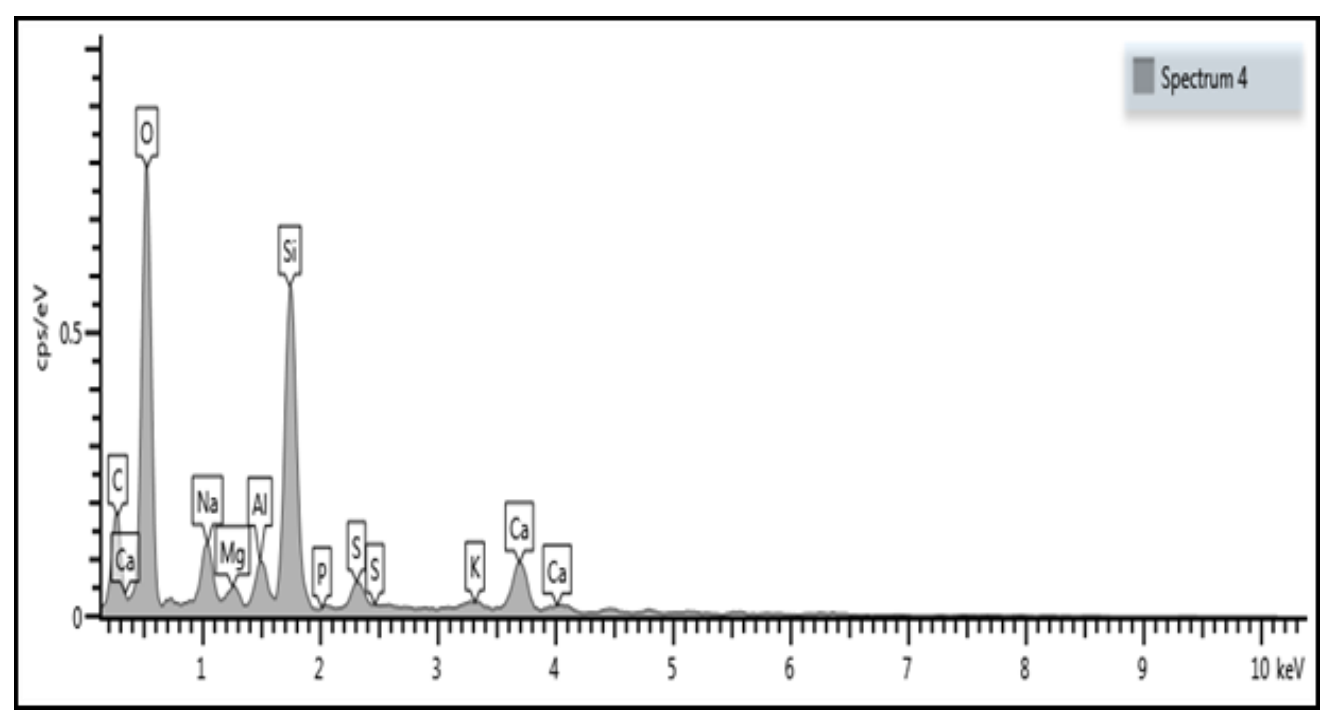

Figure 6- Results of EDS in SEM analysis of asbestos composition of Al-Shurta tunnel air sample

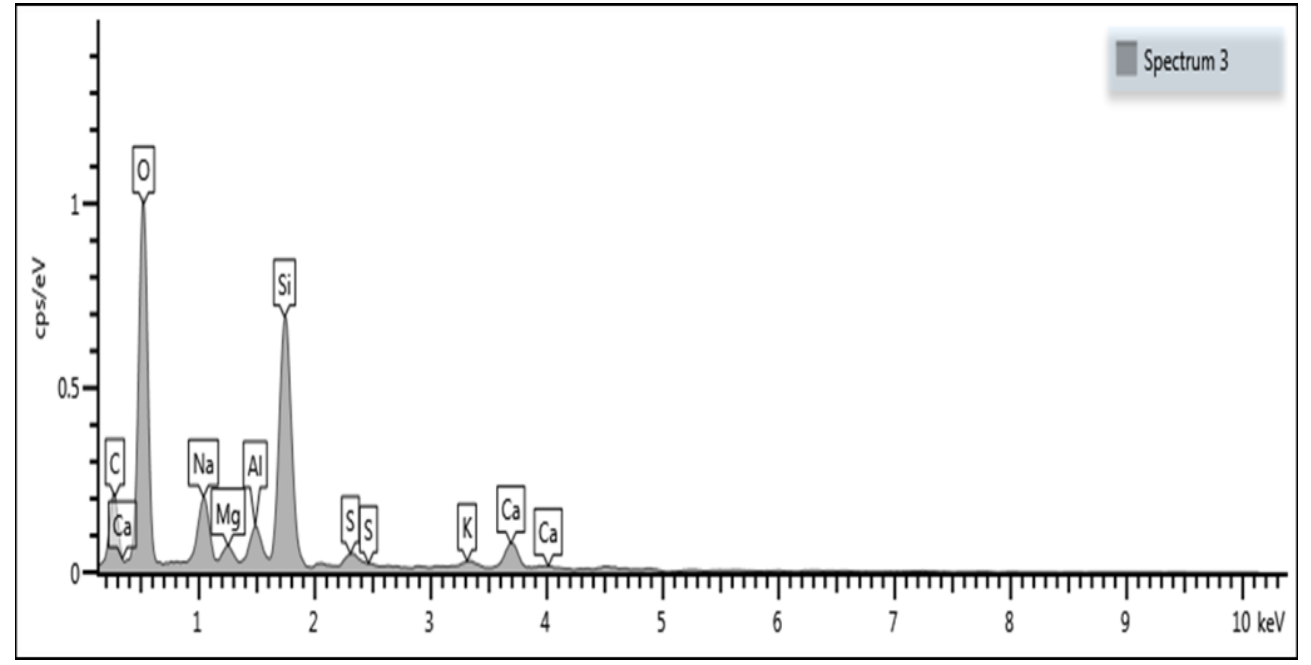

Figure 7- Results of EDS in SEM analysis of asbestos composition of Al-Meshin_complex air sample

\section{Conclusions}

The data obtained from this study indicated that the levels of the fibers of asbestos in Baghdad are above the permitted limit for ambient air suggested by the WHO. In addition, it is higher than that recommended for the European countries. The presence of different anthropogenic sources of asbestos fibers as well as heavy traffic inside and in the surroundings of the cities are considered as the major causes for the high concentrations of asbestos fibers in the air and, hence, main causes of diseases. The high level of pollution by asbestos is attributed to the commercial and industrial nature of the studied areas. Owing to the high concentration of asbestos fibers, the health of the surrounding community, occupational groups, taxi drivers and traffic officers can be negatively affected. Also low speed of wind, little rain, desertification, and reduced green areas have possibly led to low dispersion, precipitation, and self-purification of atmosphere, which resulted in accumulation of air pollutants over Baghdad city.

Therefore, the better solutions to reduce asbestos emission are represented by management of traffic by preventing the presence of heavy cars in the city at rush hours of traffic, replacing asbestos with safe substances in different materials like gear and pads of clutch, development of green spaces that can help to reduce and even eliminate asbestos fibers and other pollutants emission from the environment. Asbestos ban is also one of the important options for eliminating asbestos pollution. In Iraq, the country of the current study, asbestos was banned in 2016, according to Iraqi government's 
decision numbered 41, which decided to prohibit the production, importing, or marketing of asbestos. However, asbestos is still widely used in the country.

\section{References}

1. Mohammad, K. Ali, A. Hakimeh, T. and Yaghoub, H. 2018. Spatio-seasonal variation of airborne asbestos concentration in urban areas of Shiraz, Iran. International Journal of Occupational and Environmental Health. 23(2): 143-150.

2. Kakooei, H. and Marioryad, H. 2010. Evaluation of exposure to the airborne asbestos in an automobile brake and clutch manufacturing industry in Iran. Regul Toxicol Pharmacol. 56: 143-7 .

3. Mohammad K. and Yaghoub H. 2016. Measurement of airborne asbestos levels in high traffic areas of Shiraz, Iran, in winter 2014. International Journal of Environmental Health Engineering. $5(1)$.

4. World Health Organization (WHO). 2014. Asbestos: elimination of asbestos-related diseases http://www.who.int/mediacentre/factsheets/fs343/en/. Accessed 21 Sep 2014.

5. Pawelczyk, A. and Bozek, F. 2015. Health risk associated with airborne asbestos. Environ Monit Assess. 187(7):1-11.

6. Shahla, G. and Yaghoub, H. 2016. Monitoring of airborne asbestos fiber concentrations in high traffic areas of Isfahan, Iran in summer 2015 .International Journal of Environmental Health Engineering. 5(1).

7. Kakooei, H. and Normohammadi, M. 2014. exposure among costruction workers during demolition of old houses in Teheran, Iran. Ind. Health. 52(71).

8. Rahul, C. Shahbaz A., Varshney K., and Nabiullah K. 2017. Experimental Analysis of Asbestos Fibre Reinforced Concrete Composite. Journal of Mechanical and Civil Engineering (IOSRJMCE). 14(4):18-22.

9. Hannaniah, S. and Stephen, O. 2019. Asbestos: A Silent Potent Killer. European Journal of Environment and Public Health. 3(2).

10. Philip, E. 2012. Cancer Produced by Nonoccupational Asbestos Exposure in the United States. Journal of the Air Pollution Control Association. 33(4).

11. Katherine, M. Anne, M. and William, S. 2007. Asbestos-Related Lung Disease. American Family Physician. 75(5).

12. Neonila, S. Wojciech S., Beata S., Grazyna S., and Urszula W. 2012. Environmental Pollution Situation in Poland. International Journal of Occupational Medicine and Environmental Health. 25(1):3-13.

13. Laurie, K. 2020. The Post-Disaster Asbestos Hazard: 1995-2020. International Ban Asbestos Secretariat (IBAS).

14. Neonila, S. Beata, S. Wojciech, S. Zuzanna, S. and Urszula, W. 2015. Asbestos related diseases among workers of asbestos processing plants in relation to type of production and asbestos use. Nofer Institute of Occupational Medicine. 66(1):1-9.

15. Hossein, K. and Mohhammad, N. 2014. Asbestos exposure among construction Workers during demolition of old houses in Tehran, Iran. Industrial Health. 52: 71-77.

16. Mohammad, K. and Yaghoub, H. 2016. Measurement of airborne asbestos levels in high traffic areas of Shiraz, Iran, in winter 2014. International Journal of Environmental Health Engineering. $5(1)$.

17. ISO 14966. Ambient Air Determination of Numerical Concentration of Inorganic Fibrous Particles - Scanning Electron Microscopy Method. ISO/TC 146/ SC3; 2002.

18. Lemen, L. Yuri, K. Tetsuhisa, K. Rong, L. Masayuki, S. Norio, K. Tomoki, N. Junko, G. Tomotaka, S. 2019. Population-based cohort study on health effects of sbestos exposure in Japan. Cancer science. 2019(110):1076-1084.

19. National Institute for Occupational Safety and Health NIOSH. 2016. NIOSH Manual of Analytical Methods (NMAM), 5th Edition. Chapter FI.

20. Anca, M. 2015. Air Pollution with Asbestos in Several Cities in Romania. Advanced Topics in Environmental Health and Air Pollution Case Studies. 15(2015): 295-306.

21. Gualtieri, AF. Mangano, D. Gualtieri, ML. Ricchi, A. Foresti, E. Lesci, G. et al. 2009. Ambient monitoring of asbestos in selected Italian living areas. J Environ Manage, 2009(90):3540-3552. 
22. Mensi, C. DeMatteis, S. Dallari, B. Riboldi, L. Bertazzi, P. Consonni, D. 2016. Incidence ofmesothelioma in Lombardy, Italy: Exposure to asbestos, time patterns and future projections. Occupational and environmental medicine. 73: 607-613.

23. World Health Organization (WHO). 2014. Asbestos: elimination of asbestos-related diseases.

24. Sonja, K. James, L. Douglas, W. and Markku, N. 2020. Asbestos, Smoking and Lung Cancer: An Update. International Journal of Environmental Research and Public Health, 17(258).

25. Luigi, V. Domenica, C. Maria, C. Antonio, C. Luigi, D. and Stefania, S. 2020. Asbestos Air Pollution: Description of a Mesothelioma Cluster Due to Residential Exposure from an Asbestos Cement Factory. International Journal of Environmental Research and Public Health. 17(2636).

26. Metintas, S. and Metintas, M. 2019. A review of the cohorts with environmental and occupational mineral fiber exposure. Arch. Environ. Occup. Health. 74: 76-84.

27. Mazzeo, A. 2019. Narrating and remembering as practices of care, community, and commitment in asbestos contaminated contexts. Ann. Dell'istituto Super. Di Sanita. 55: 94-99.

28. Andrzej, O. 2020. Asbestos in building and its destruction. Construction and Building Materials. 249(118685).

29. Laurie, K. 2020. The Post-Disaster Asbestos Hazard: 1995-2020. International Ban Asbestos Secretariat (IBAS).

30. Laurie, K. 2019. Chronology of Asbestos Bans and Restrictions. International Ban Asbestos Secretariat (IBAS) 